\title{
VALIDATION OF POLISH VERSION OF THE QUESTIONNAIRE FOR EVALUATION OF PARENTS/CAREGIVERS SATISFACTION WITH NURSING CARE IN A PAEDIATRIC WARD
}

\author{
WALIDACJA POLSKIEJ WERSJI JĘZYKOWEJ KWESTIONARIUSZA OCENY \\ POZIOMU ZADOWOLENIA RODZICÓW/OPIEKUNÓW Z OPIEKI PIELĘGNIARSKIEJ \\ NA ODDZIALE PEDIATRII
}

\author{
${ }^{1}$ Chair and Department of Management in Nursing, Faculty of Nursing and Health Sciences, \\ Medical University, Lublin \\ ${ }^{2}$ Doctroral studies, II Faculty of Medicine with English Language Division, Medical University, Lublin
}

\begin{abstract}
S u m m a r y
Introduction. The questionnaire Parent satisfaction in paediatric intensive care by Latour et al. is a standardized instrument used in the measurement of parents' satisfaction with care in an intensive care unit in Rotterdam, Holland.

The objective of the study was to present the process of validation of a research instrument and adaptation of the questionnaire Parents/caregivers satisfaction with nursing care for measuring satisfaction with nursing care in paediatric wards in Poland.

Material and methods. Studies on validation of the instrument were conducted during the period of 20122013, in Polish general paediatric wards and paediatric intensive care units in hospitals with the $3^{\text {rd }}$ reference level in the regions of Rzeszów and Olsztyn. After analyzing the instruments applied for measuring satisfaction with care published in international literature, the questionnaire for evaluation of satisfaction by Latour et al. was selected. The text of the questionnaire was translated and questions posed commensurate with the Polish conditions. Subsequently, the understanding of the questions was assessed in a group of 15

Specialist Health Care Unit in Sanok. Then, the validity and reliability of the Polish version of the instrument was evaluated in the group of 115 parents of children hospitalized in a paediatric ward and 100 nurses employed in paediatric care wards in the regions of Rzeszów and Olsztyn. Psychometric properties of the instrument were analyzed using factor analysis and Cronbach's alpha coefficient.

Results. The validation process allowed an observation of a high level of understanding in both groups examined of the contents of questions in the instrument for the measurement of satisfaction. This is confirmed by the value of Cronbach's alpha coefficient in individual blocks of items of over 0.8 , which showed a high reliability of the test.

$\mathrm{Conclusions}$. The results obtained in the process of validation of the instrument confirmed that the questionnaire Parents/caregivers satisfaction with nursing care satisfies a high level of reliability and validity. Therefore, this questionnaire may be used in the studies concerning the assessment of the level of parents'/caregivers' satisfaction of with care in general paediatric wards and paediatric intensive care units in Poland.
\end{abstract} parents of children hospitalized in the paediatric ward in the

\section{Streszczenie}

W stęp. Kwestionariusz Zadowolenia rodziców $\mathrm{Z}$ opieki autorstwa Latour i wsp. to standaryzowane narzędzie stosowane $\mathrm{w}$ pomiarze satysfakcji $\mathrm{z}$ rodziców $\mathrm{z}$ opieki na oddziale intensywnej terapii w Rotterdamie w Holandii.
Cel pracy. Przedstawienie procesu walidacji narzędzia badawczego i adaptacji kwestionariusza Zadowolenia rodziców/opiekunów $\mathrm{z}$ opieki pielęgniarskiej 
dla potrzeb pomiaru satysfakcji z opieki pielęgniarskiej na oddziałach pediatrii w Polsce.

Materiał i metody. Badania nad walidacją narzędzia prowadzono w 2012 i 2013 roku w krajowych oddziałach pediatrii ogólnej oraz intensywnej terapii dzieci w szpitalach trzech poziomów referencyjnych województwa podkarpackiego i mazursko-warmińskiego w Polsce. Po przeanalizowaniu narzędzi stosowanych $\mathrm{w}$ pomiarze satysfakcji $\mathrm{z}$ opieki opublikowanych $\mathrm{w}$ piśmiennictwie zachodnim, wybrano Kwestionariusz oceniający zadowolenie z opieki autorstwa Latour i wsp. Po przethumaczeniu tekstu kwestionariusza pozostawiono pytania adekwatne do polskich warunków. Następnie dokonano oceny zrozumienia pytań w grupie 15 rodziców dzieci hospitalizowanych na oddziale pediatrii Szpitala Specjalistycznego Zespołu Opieki Zdrowotnej w Sanoku. W dalszej kolejności oceniono trafność i rzetelność polskiej wersji narzędzia w grupie 115 rodziców hospitalizowanych na oddziale pediatrii oraz 100 pielęgniarek pracujących na oddziałach dziecięcych w województwie podkarpackim i warmińsko-mazurskim. W określaniu właściwości psychometrycznych narzędzia zastosowano analizę czynnikową oraz współczynnik $\alpha$-Cronbacha.

Wyniki. Proces walidacji pozwolił na stwierdzenie wysokiego stopnia zrozumienia $\mathrm{w}$ obu grupach badanych treści pytań w narzędziu do pomiaru satysfakcji. Wskazuje na to wartość współczynnika $\alpha$-Cronbacha poszczególnych bloków pytań powyżej 0,8, potwierdzająca wysoką rzetelność testu.

Wnioski. Wyniki osiągnięte $\mathrm{w}$ procesie walidacji narzędzia pozwoliły na stwierdzenie, że kwestionariusz Zadowolenia rodziców/opiekunów z opieki spełnia wysoki stopień rzetelności oraz trafności. Dlatego może być stosowany w badaniach dotyczących oceny poziomu satysfakcji rodziców/opiekunów z opieki na oddziale ogólnopediatrycznym oraz intensywnej opieki dla dzieci w Polsce.

Key words: satisfaction, measurement, research instrument, paediatrics, nursing care

Slowa kluczowe: satysfakcja, pomiar, narzędzie badawcze, pediatria, opieka pielęgniarska

\section{INTRODUCTION}

Changes taking place in the system of health care, humanization of medicine, and holistic approach to the object of care, as well as striving towards the highest quality of the offered services possible, increase interest in the measurement of satisfaction with care [1]. A high level of satisfaction of services' recipients is a basic indicator of the optimum quality of care provided by a health care facility [2, 3]. Recipient's satisfaction with the services provided is an expression of the good quality of care which increases the competitiveness of the care provider on the market of health services $[4,5]$. The primary principle of quality standards by the International Organization for Standardization (ISO) is the orientation towards the client and related with it determination of the services recipient's level of satisfaction, which facilitates a simultaneous recognition and understanding of the current demands and expectations [6]. The measurement of satisfaction with care is an important element in the management of a health care facility [7], and an element of the assessment of the quality of care $[6,8]$.

Satisfaction (Lat. satisfactio - reparation) is defined as a feeling of being pleased, content, e.g. because of something that one achieved or obtained [9]. According to Lenartowicz, it is related with personal expectations, personal values and experience. The measurement of the level of satisfaction is a valuable source of information concerning the services provided [10]. Satisfaction defined as a feeling of content is a resultant between expectations and the effect obtained. The smaller the discrepancy between expectations and effects, the higher the level of satisfaction [6, 8]. According to the American Nurses Association (ANA), patient satisfaction is the measure of a client's opinion with respect to nursing care provided within medical services during a stay in a health care facility [11]. This is the most important indicator of a patient's satisfaction with complex hospital care [4]. This was confirmed in studies by Otani et al. which indicated that nursing care is of the utmost importance for an overall satisfaction with hospitalization [12].

In paediatric patients, the evaluation of satisfaction is performed by parents or caregivers [2] who, at the same time, exert an effect on the planning of care [13]. A high level of parents' satisfaction with care increases trust in paediatric care and is an important indicator of the quality of care [7].

Various methods, techniques and research instruments are used in the measurement of satisfaction. The researchers investigating this aspect of quality use self-designed and standardized questionnaires [8]. However, only genuine and reliable instruments allow the actual assessment of the level of satisfaction [1, 8]. These functions are fulfilled by standardized instruments for the measurement of satisfaction of parents and caregivers with nursing care [14]. For many years in the Western countries an interest has been observed in the measurement of 
satisfaction with care in paediatrics, whereas in Poland, the problem of parents/caregivers satisfaction with care is less popular. Therefore, it seems justifiable to examine the indicator of the quality of care which is parents/caregivers satisfaction with care in Poland [15].The authors of the presented study reviewed several dozen instruments used in the measurement of satisfaction with care in West European countries and in the USA. After comprehensive analysis the most optimum instrument was selected which, however, required cultural adaptation and validation in order to be applied in Poland. The questionnaire 'Parents/caregivers satisfaction with care' is a standardized instrument used for the measurement of parents' satisfaction with care in an intensive care unit in Rotterdam, Holland.

The objective of the study was to present the process of validation of a research instrument and adaptation of the questionnaire Parents/caregivers satisfaction with nursing care for measuring satisfaction with nursing care in paediatric wards in Poland.

\section{MATERIAL AND METHODS}

Studies on validation of the instrument were conducted during the period of 2012-2013 in Polish general paediatric wards and paediatric intensive care units in hospitals with three reference levels in the regions of Rzeszów and Olsztyn. After analyzing the instruments applied for the measurement of satisfaction with paediatric care published in international literature, the Questionnaire Parents/caregivers satisfaction with nursing care by Latour et al. was selected. In 2006, Latour et al., based on opinions of professionals employed in a paediatric intensive care unit, selected a set of factors influencing parents' satisfaction with care. The above-mentioned researchers prepared a 78-item questionnaire for the needs of assessment of satisfaction which, after pilot studies, was applied in paediatric wards in Holland. The study was conducted in eight paediatric intensive care units in hospitals with the $3^{\text {rd }}$ reference level. The replies provided by parents were divided into 5 domains, i.e. information, care and cure, organization, parental participation, and professional attitude. After analyzing the results of the study the final version contained 74 items grouped in the 5 above-mentioned domains of satisfaction [13].
Adaptation of the questionnaire to the Polish conditions covered linguistic and psychometric validation. Validation is the procedure for testing validity, reliability and accuracy of the measurement scales applied in the study.

Linguistic validation of the instrument. After obtaining consent to use the questionnaire, the text was translated into Polish. The translation of the original version into Polish was performed by two independent translators. After obtaining two translations, the authors reached consensus on one version; the questionnaire was modified by shortening the original version of the instrument. The premise was that the instrument was excessively long, and additionally evaluated procedures performed by physicians which, in Poland, are not the nurses' responsibility. Other detailed criteria concerning tasks which are also not performed by Polish nurses, e.g. informing parents/caregivers about the state of health of a child were also omitted. After reaching agreement concerning the best and most valid version of the questionnaire, retranslation to the source language was performed. The translator was a native speaker, whose natural language was that in which the original version of the instrument was developed. Subsequently, the English version was again translated into Polish, and then the text compared with the earlier version in Polish. Comparative analysis showed a high level of linguistic conformity between the former and final versions of translation into Polish. Subsequently, the final version of the questionnaire was modified. The goal was an assessment of understanding and usefulness for measurement in Polish conditions. For the needs of linguistic validation, the instrument was tested in a representative group of the population among whom its application was planned. The group evaluating the questionnaire from the aspect of understanding the criteria were 15 parents of children hospitalized in a paediatric ward, and 15 nurses employed in the ward of the Specialist Health Care Facility in Sanok. The pilot studies were anonymous and voluntary. Consent for the study was obtained from the Bioethics Committee at the Medical University in Lublin, No. KE-0254/163/2012, Board of Directors of the Health Care Facilities in Sanok and Olsztyn managing the paediatric ward. After consideration of the opinions of parents/caregivers, the researchers made minor corrections and adopted the final version of the instrument. Ultimately, the questionnaire consisted of 5 main domains: 1) 
information, 2) care and cure, 3) organization, 4) parental participation, and 5) professional attitude. The questionnaire contained a total number of 44 detailed items aimed at evaluation of the level of satisfaction of parents/caregivers with nursing care. The first domain concerning information provided by nurses contained 8 items. The second domain consisted of 9 items related with assessment of satisfaction with nursing activities in the area of care and cure. The third domain of the questionnaire contained a smaller number of items, only 2 , concerning the availability of a nurse. The fourth domain concerned the engagement of parents in the process of treatment and hospitalization and contained 6 items. The final domain in the questionnaire was related with the evaluation of the degree of professional attitude towards the nursing care provided and contained the largest number of items (19). Parents/caregivers assessed individual elements of satisfaction using a 5-degree Likert scale, where the value 1 was the lowest degree of satisfaction, while 5 maximum level of satisfaction with care.

Psychometric validation. The objective was the evaluation of validity and reliability of the Polish version of the instrument. Evaluation of psychometric properties with the use of the translated version of the research instrument was performed by means of factor analysis and and Cronbach's alpha coefficient. It is recommended that the number of population in the study group was at least twice as large as the number of items in the questionnaire. Theoretical validity was carried out in a group of 115 parents of children hospitalized in paediatric wards and 100 charge nurses employed in paediatric wards in the Regions of Rzeszów and Olsztyn. The nurses' task (the method of competent judges) was evaluation of the research instrument from the aspect of performance of nursing activities in accordance with the scope of duties and responsibilities.

\section{RESULTS}

The process of validation of the instrument allowed confirmation of a high degree of understanding of the instrument for the measurement of satisfaction. This is confirmed by the value of Cronbach's alpha coefficient in individual blocks of items of over 0.8 .

The results obtained show a high reliability of the test. Based on the results of Cronbach's alpha it may be presumed that high parameters of reliability of the research instrument were obtained, with Cronbach's alpha coefficient of 0.965 (Tab. I).

Table I. Analysis of reliability of the questionnaire items

\begin{tabular}{|c|l|c|c|}
\hline \multicolumn{2}{|c|}{ Variables } & $\mathrm{N}$ & $\%$ \\
\hline \multirow{3}{*}{ Observations } & Important & 173 & 80.5 \\
\cline { 2 - 4 } & Deleted $^{\text {a }}$ & 42 & 19.5 \\
\cline { 2 - 4 } & Total & 215 & 100.0 \\
\hline \multicolumn{3}{|c|}{ Statistical reliability } \\
\hline $\begin{array}{c}\text { Cronbach's } \\
\text { alpha }\end{array}$ & $\begin{array}{l}\text { Cronbach's alpha based on } \\
\text { standardized items }\end{array}$ & $\begin{array}{c}\text { Number } \\
\text { of items }\end{array}$ \\
\hline 0.962 & 0.965 & 44 \\
\hline
\end{tabular}

a Deleting observations considering all variables in the analysis

Source: Based on data obtained in own studies

Table II. Analysis of reliability of individual sections of the research instrument

\begin{tabular}{|c|c|c|c|c|}
\hline No. & Main criteria & & $\mathrm{N}$ & $\%$ \\
\hline \multirow{7}{*}{1.} & \multirow{3}{*}{ Observations } & Important & 200 & 93.0 \\
\hline & & Deleted $^{\mathrm{a}}$ & 15 & 7.0 \\
\hline & & Total & 215 & 100.0 \\
\hline & \multirow{4}{*}{ Information } & Statistical reliability & & \\
\hline & & \begin{tabular}{|l|} 
Cronbach's alpha \\
\end{tabular} & Number of items & \\
\hline & & 0.853 & 8 & \\
\hline & & & $\mathrm{N}$ & $\%$ \\
\hline \multirow{6}{*}{2.} & \multirow{3}{*}{ Observations } & Important & 193 & 89.8 \\
\hline & & Deleted $^{\mathrm{a}}$ & 22 & 10.2 \\
\hline & & \begin{tabular}{|l|} 
Total \\
\end{tabular} & 215 & 100.0 \\
\hline & \multirow{3}{*}{ Care and cure } & Statistical reliability & & \\
\hline & & Cronbach's alpha & Number of items & \\
\hline & & 0.912 & 9 & \\
\hline \multirow{7}{*}{3.} & \multirow{4}{*}{ Observations } & & $\mathrm{N}$ & $\%$ \\
\hline & & Important & 214 & 99.5 \\
\hline & & Deleted $^{\mathrm{a}}$ & 1 & .5 \\
\hline & & Total & 215 & 100.0 \\
\hline & \multirow{3}{*}{ Availability of a nurse } & Statistical reliability & & \\
\hline & & Cronbach's alpha & Number of items & \\
\hline & & 0.926 & \begin{tabular}{|c|}
2 \\
\end{tabular} & \\
\hline \multirow{7}{*}{4.} & \multirow{4}{*}{ Observations } & & $\mathrm{N}$ & $\%$ \\
\hline & & Important & 202 & 94.0 \\
\hline & & Deleted $^{\mathrm{a}}$ & 13 & 6.0 \\
\hline & & Total & 215 & 100.0 \\
\hline & \multirow{3}{*}{ Parental participation } & Statistical reliability & & \\
\hline & & \begin{tabular}{|l|} 
Cronbach's alpha \\
\end{tabular} & Number of items & \\
\hline & & 0.786 & \begin{tabular}{|c|}
6 \\
\end{tabular} & \\
\hline \multirow{7}{*}{5.} & \multirow{4}{*}{ Observations } & & $\mathrm{N}$ & $\%$ \\
\hline & & Important & 192 & 89.3 \\
\hline & & Deleted $^{\mathrm{a}}$ & 23 & 10.7 \\
\hline & & Total & 215 & 100.0 \\
\hline & \multirow{3}{*}{$\begin{array}{c}\text { Professionalism / } \\
\text { professional attitude }\end{array}$} & Statistical reliability & & \\
\hline & & \begin{tabular}{|l|} 
Cronbach's alpha \\
\end{tabular} & Number of items & \\
\hline & & 0.909 & 19 & \\
\hline
\end{tabular}

a Deleting observations considering all variables in the analysis

Source: Based on data obtained in own studies

While analyzing the 5 individual domains of the questionnaire, small differences were found in the value of Cronbach's alpha coefficient (Tab. II). The lowest values were obtained in the area concerning the 
Table III. Value of Cronbach's alpha for individual items in the questionnaire

\begin{tabular}{|c|c|c|c|c|c|}
\hline \multirow[b]{2}{*}{ No. } & \multicolumn{5}{|c|}{ Statistics of items } \\
\hline & Contents of an item & $\begin{array}{c}\text { Mean value } \\
\text { of scale after } \\
\text { deleting an } \\
\text { item }\end{array}$ & $\begin{array}{c}\text { Variance } \\
\text { of scale after } \\
\text { deleting an } \\
\text { item }\end{array}$ & $\begin{array}{l}\text { Correlation } \\
\text { of items total }\end{array}$ & $\begin{array}{c}\text { Cronbach's alpha } \\
\text { after deleting an } \\
\text { item }\end{array}$ \\
\hline 1. & Nurse informed about principles of child's care & 183.2254 & 612.420 & 0.693 & 0.961 \\
\hline 2. & Nurse provided no conflicting information & 183.0058 & 627.796 & 0.517 & 0.961 \\
\hline 3. & Nurse provided understandable and adequate information & 182.7919 & 628.015 & 0.568 & 0.961 \\
\hline 4. & Nurse informed about changes in child's care & 183.1445 & 621.927 & 0.543 & 0.961 \\
\hline 5. & Nurse daily informed about child's care & 183.7630 & 617.287 & 0.512 & 0.962 \\
\hline 6. & Nurse informed about child's care at the right time & 183.2601 & 627.019 & 0.466 & 0.962 \\
\hline 7. & Nurse informed about rules in the ward & 183.0867 & 620.242 & 0.590 & 0.961 \\
\hline 8. & Nurse informed about visiting hours & 183.0000 & 615.907 & 0.580 & 0.961 \\
\hline 9. & Nurse was alert to child's discomfort & 182.9364 & 620.444 & 0.677 & 0.961 \\
\hline 10. & Nurse reacted promptly to changes in child's condition & 182.7977 & 622.941 & 0.643 & 0.961 \\
\hline 11. & Nurse participated in prevention/alleviation of pain complaints & 182.7803 & 624.742 & 0.639 & 0.961 \\
\hline 12. & Nurse gave medication at the right time & 182.6301 & 626.444 & 0.637 & 0.961 \\
\hline 13. & $\begin{array}{l}\text { Nurse possessed information concerning bio-psycho-social status of } \\
\text { the child }\end{array}$ & 183.1214 & 618.654 & 0.718 & 0.961 \\
\hline 14. & Nurse provided emotional support & 183.2081 & 616.003 & 0.753 & 0.960 \\
\hline 15. & Nurse provided spiritual support & 183.4798 & 619.693 & 0.604 & 0.961 \\
\hline 16. & \begin{tabular}{|lcccccc}
$\begin{array}{l}\text { Nurse displayed } \\
\text { parents/caregivers }\end{array}$ & a caring & attitude towards & child & and \\
\end{tabular} & 183.1214 & 614.084 & 0.788 & 0.960 \\
\hline 17. & Nurse prepared for home care at discharge from the ward & 183.3931 & 608.461 & 0.755 & 0.960 \\
\hline 18. & Nurse was available for the child when necessary & 182.8960 & 624.210 & 0.741 & 0.961 \\
\hline 19. & Nurse was available for parents/caregivers as necessary & 182.9653 & 621.289 & 0.768 & 0.961 \\
\hline 20. & Parents cooperated with the nursing team & 183.0405 & 633.772 & 0.395 & 0.962 \\
\hline 21. & Nurse prepared parents/caregivers for child's care & 183.1908 & 617.853 & 0.726 & 0.961 \\
\hline 22. & $\begin{array}{l}\begin{array}{l}\text { Nurse asked about parents/caregivers expectations concerning } \\
\text { child's care }\end{array} \\
\end{array}$ & 183.4566 & 613.982 & 0.701 & 0.961 \\
\hline 23. & $\begin{array}{l}\text { Nurse encouraged parents/caregivers to be close to their child during } \\
\text { hospitalization }\end{array}$ & 183.0405 & 617.341 & 0.672 & 0.961 \\
\hline 24. & $\begin{array}{l}\text { Parents/caregivers actively shared decision-making on the care of } \\
\text { their child }\end{array}$ & 182.8960 & 635.954 & 0.386 & 0.962 \\
\hline 25. & $\begin{array}{l}\text { Nurse stimulated parents/caregivers to stay close to their child during } \\
\text { nursing procedures and test }\end{array}$ & 183.1676 & 627.350 & 0.503 & 0.962 \\
\hline 26. & Cooperation within nursing-medical team was clearly observed & 182.8960 & 627.059 & 0.584 & 0.961 \\
\hline 27. & $\begin{array}{l}\text { Parent/caregivers knew which nurse was responsible for the care of } \\
\text { their child }\end{array}$ & 183.2948 & 609.104 & 0.754 & 0.960 \\
\hline 28. & Nurse introduced herself with name and surname & 183.9769 & 602.918 & 0.658 & 0.961 \\
\hline 29. & Nurse's work on duty was well organized & 182.9884 & 622.349 & 0.709 & 0.961 \\
\hline 30. & Work of nursing team provided the child with a sense of safety & 182.9653 & 620.092 & 0.762 & 0.961 \\
\hline 31. & The closest environment of the child was clean & 182.8150 & 626.105 & 0.661 & 0.961 \\
\hline 32. & $\begin{array}{l}\text { Written information on rules in the ward were in place available for } \\
\text { parents/caregivers }\end{array}$ & 183.0636 & 625.816 & 0.524 & 0.961 \\
\hline 33. & Admission hours were flexible & 182.8960 & 634.512 & 0.374 & 0.962 \\
\hline 34. & $\begin{array}{l}\text { Accommodation for parents/caregivers nearby the ward was } \\
\text { provided }\end{array}$ & 183.3064 & 628.074 & 0.326 & 0.963 \\
\hline 35. & $\begin{array}{l}\text { Nurse provided high quality care irrespective of race, religion, } \\
\text { gender and education }\end{array}$ & 182.6474 & 631.253 & 0.617 & 0.961 \\
\hline 36. & Nurse safeguarded privacy of a child & 182.7977 & 626.604 & 0.685 & 0.961 \\
\hline 37. & Nurse safeguarded privacy of parents & 182.8786 & 623.654 & 0.644 & 0.961 \\
\hline 38. & Nurse respected parents/caregivers & 182.6936 & 634.446 & 0.508 & 0.962 \\
\hline 39. & Nurse refrained from unnecessary discussions at the child's bedside & 182.8728 & 631.530 & 0.490 & 0.962 \\
\hline 40. & Nurse showed empathy towards the child & 183.0751 & 626.919 & 0.426 & 0.962 \\
\hline 41. & Nurse showed empathy towards parents/caregivers & 183.2139 & 621.983 & 0.504 & 0.962 \\
\hline 42. & Nurse welcomed parents/caregivers at admission/visits & 182.9884 & 627.732 & 0.529 & 0.961 \\
\hline 43. & $\begin{array}{l}\text { Work pressure did not affect the level of services provided by nurse } \\
\text { on behalf of the child }\end{array}$ & 182.9133 & 625.196 & 0.677 & 0.961 \\
\hline 44. & Child's health was a priority for the nurse & 182.7399 & 624.077 & 0.761 & 0.961 \\
\hline
\end{tabular}

Source: Based on data from own studies

engagement of parents in the process of treatment and care of a child (0.786). Slightly higher values were indicated in the section of the questionnaire concerning the provision of information (0.853). Similar correlations were obtained with respect to professional attitude (0.909), and care and cure (0.912). The highest values of Cronbach's alpha coefficient were obtained for availability of nurses for the child and parents (0.926). Table II presents detailed results. 
Individual detailed criteria of the questionnaire were also analyzed. It was assumed that the value of Cronbach's alpha coefficient of 0.8 confirms a high reliability of the test in psychometric validation of the research instrument (Tab. III). Analysis of the results contained in the Table shows that a relatively high correlation of the results was obtained, and none of the variables interfered with the whole of the analyses. The obtained value of Cronbach's alpha coefficient from $0.960-0.963$ confirms a high reliability of the test. Table III presents detailed results concerning the values of Cronbach's alpha for all detailed criteria in the research instrument.

\section{CONCLUSIONS}

The conclusions drawn during the process of validation of the instrument allowed the presumption that the questionnaire Parents/caregivers satisfaction with nursing care satisfies a high level of reliability and validity; therefore, it may be applied in studies concerning the evaluation of the level of parents/caregivers satisfaction with care in a general paediatric wards and paediatric intensive care units in Poland.

An increase in the expectations of care recipients, concern about the high quality of services, competitiveness of health care facilities, and the possibility of choosing a care provider by a client contribute to offering of the best possible quality of services. The demand for services is conditioned by clients' actual needs and expectations. Thus, the measurement of satisfaction with the services offered occupies an important position in the recognition of the demand for services.

\section{REFERENCES}

1. Vuori H.: Patient satisfaction: a valid concept. Soc Sci Med. 1994; 38(4): 509-516.

2. Dosier S.J.: Satisfaction determinants: parents with children admitted to an adult inpatient surgical unit. Montana State University, Bozeman 2006.

3. Matziou V., Boutopoulou B., Chrysostomou A., Vlachioti E., Mantziou T., Petsios K.: Parents' satisfaction concerning their child's hospital care. Japan Journal of Nursing Science 2011; 8, 163-173.

4. Dyk D., Gutysz-Wojnicka A.: Analiza terminologiczna pojęcia „satysfakcja pacjenta". W: Problemy wielokulturowe $\mathrm{w}$ medycynie. Krajewska-Kułak E., Wrońska I., Kędziora-Kornatowska K. (red.). Wydawnictwo Laekarskie PZWL Warszawa 2010; 190196.
5. Peña Y.F., Silvia Esthela Vázquez R. de la Gala S., E., Cerda-Flores R.M: Maternal satisfaction with maternalinfant nursing care in Campeche, Mexico. Rev Latinoam Enfermagem 2009; 17(5):645-50

6. Dobska M., Rogoziński K. (red.).: Podstawy zarządzania zakładem opieki zdrowotnej. Wydawnictwo PWN. Warszawa 2008.

7. Weissenstaein A., Straeter A., Villalon G., et al.: Parent satisfaction with a pediatric pratice in Germany: A questionnaire-based study. Italian Journal of Pediatrics 2011, 37:31-36.

8. Trzebiatowska I.: Satysfakcja jako element oceny jakości opieki. W: Ocena jakości opieki paliatywnej w teorii i praktyce. de Walden-Gałuszko K., Majkowicz M. (red). Wyd. Akademia Medyczna, Gdańsk 2000. s. 16-20

9. Szkiłądź H. (red.): Słownik wyrazów obcych Wydawnictwo PWN. Warszawa 1980.

10. Lenartowicz H.: Zarządzanie jakością w pielęgniarstwie. Materiały dydaktyczne specjalizacji organizacja i zarządzanie. Wydawnictwo Centrum Edukacji Medycznej. Warszawa 1998.

11. American Nurses Association: ANA Indicator History. http://www.nursingworld.org/ z dnia 11.09.2012.

12. Dyk D., Gutysz-Wojnicka A.: Analiza terminologiczna pojęcia „satysfakcja pacjenta”. W: Problemy wielokulturowe w medycynie. Krajewska-Kułak E., Wrońska I., Kędziora-Kornatowska K. (red.). Wydawnictwo Lekarskie PZWL Warszawa 2010; 190196, za Otani K., Kurz R.S.: The impact of nursing care and other atributes on hospitalized satisfaction and behavioral intentions. JHM, 2004, 46; 181-196.

13. Latour J.M, Hazelzet J.A., Duivenvoorden H.J., et al. Construction of a parent satisfaction instrument: Perceptions of pediatric intensive care nurses and physicians. Journal of Critical Care 2009; 24; 255-266.

14. Weissenstaein A., Straeter A., Villalon G., Luchter E., Bittman S.: Parent satisfaction with a pediatric pratice in Germany: A questionnaire-based study. Italian Journal of Pediatrics 2011, 37; 31-36.

15. Conner JM., Eugene C. Nelson EC.: Neonatal Intensive Care: Satisfaction Measured From a Parent's Perspective. Pediatrics 1999, Vol. 103 No. 1, Suplement; 336-349.

16. Smoleń E., Ksykiewicz-Dorota A.: Przegląd narzędzi stosowanych w pomiarze satysfakcji rodziców/opiekunów z opieki w pediatrii. Przegl Pediatr 2013; 43(1); 30-34

Address for correspondence:

Ewa Smoleń

Instytut Medyczny

Państwowa Wyższa Szkoła Zawodowa

im. Jana Grodka

ul. Mickiewicza 21

38-500 Sanok

e-mail: ewasmolen@op.pl

tel. 667249796

fax 134655959

Received: 3.10.2014

Accepted for publication: 10.03.2015 